\title{
Antioxidant potential of some Sudanese medicinal plants used in traditional medicine
}

\author{
Hatil H. Elkamali ${ }^{1}$, Sana E. M. Hamed ${ }^{2}$ \\ ${ }^{I}$ Faculty of Science and Technology, Omdurman Islamic University, Omdurman, Sudan \\ ${ }^{2}$ Faculty of Medical Laboratories, Omdurman Islamic University, Omdurman, Sudan \\ *Corresponding author E-mail:htlkamali@yahoo.com
}

Copyright $\odot$ 2015Hatil H. Elkamali, Sana E. M. Hamed. This is an open access article distributed under the Creative Commons Attribution License, which permits unrestricted use, distribution, and reproduction in any medium, provided the original work is properly cited.

\begin{abstract}
In the present work methanolic and water extracts of 19 medicinal plants, commonly used in Sudanese folk medicines against gastrointestinal tract, infectious diseases were investigated for their antioxidant activity. Antioxidant assays were carried out by using different in vitro models such as DPPH (2, 2-diphenyl-1picrylhydrazyl) radical scavenging and Iron chelating activity. Methanolic and water extracts of Punica granatum showed the highest total antioxidant activity of $71 \pm 0.03$ and $73 \pm 0.01$ respectively. The antioxidant activities of water extracts were poor when compared to the methanol extract. The iron chelating power of methanol and aqueous extracts of Commiphora myrrha $58 \pm 0.01$ and Azadirachta indica $57 \pm 0.20$ respectively.
\end{abstract}

Keywords:Antioxidant Activity; Free Radical; Polar Extracts; Sudanese Flora.

\section{Introduction}

An antioxidant is a molecule capable of slowing or preventing the oxidation of other molecules [1].Free Free radical are chemical species, which contains one or more unpaired electron due to which they are highly unstable and cause damage to other molecules by extracting electron from them in order to attain stability [2].Antioxidants Antioxidants terminate these chain reactions by removing free radical intermediates, and inhibit other oxidation reactions by being oxidized themselves [1]. When the generation of these species exceeds the levels of antioxidant mechanism, it leads to oxidative damage of tissues and biomolecules, eventually leading to disease conditions, especially degenerative diseases [3].

Many Sudanese medicinal plants are considered potential sources of antioxidants compounds. In some cases, other active constituents are known. Punica granatum, Acacia nilotica, Terminalia chebula, all of which have antioxidants activity, showed high content of phenolic like gallic acid [4-6].

Commiphora myrrh useful herbal remedies for controlling oxidative damages and genotoxicity induced by lead acetate intoxication [7].The best protection against squalene peroxidation provided by Myrrha essential oils [8].

Punicagranatumethanolic and aqueous extracts revealed high antioxidant activity [9]. A high correlation between antioxidant capacity and proanthocyanin, ellagitannins contents was found

Phenolics, flavonoids, anthocyanins, and tannins of $P$. granatum juices, were investigated. A high correlation between antioxidant capacity and proanthocyanin, ellagitannins contents was found [10],[11]. The antioxidant capacity of $P$. granatum peel extracts was 10 times higher than the pulp extracts and has more potential effective compound [12]. This difference in antioxidant activity due to the presence of $P$. granatum peel tannins, anthocyanins and ellagic acid derivatives [13].daily Daily intakes of $P$. granatum by-product augment the human immune system's antioxidant capacities [14].Severe erosion of gastric mucosa treated bymethanolic extract of P.granatum fruit rind [15].

Acacia nilotica bark was active with $75 \%$ inhibition for the scavenging of superoxide-freeradicals barks $78 \%$ and fruits $(66 \%)$ showed over $50 \%$ inhibition of glycation production assay [16]. A significant correlation was recognized between the phenolic content and antioxidant properties of Indian Acacia nilotica [17]. The high scavenging property of 
A. nilotica may be due to hydroxyl groups existing in the phenolic compounds that can scavenge the free radicals. It has an inspiring range of medicinal uses with potential antioxidant activity [18].

Furanocoumarins were one of the main active constituents of Ruta graveolens and were also reported to be potent antioxidants while total phenolic content showed good correlation with nitric oxide reduction potential. Antioxidant activity of in vitro, culture was significantly higher compared to in vivo plant material [19],[20].

Terminalia chebula were investigated for antilipid peroxidation, antisuperoxide radical formation and free radical scavenging activities [21-27]. T. chebula fruits had the potential to play a role in the hepatic prevention of oxidative damage in living systems [28].

Triphala, a composite mixture of Terminalia chebula, Terminalia belerica and Emblica officinalis, supplementation exerted antioxidants effect and regarded as protective drug against stress [29]. Triphala effectively useful in the treatment of constipation and other gastric problems, appetite and the amount, frequency and consistency of stool were improved [29],[30]. Also were used for treatment of disorders related to respiratory tract, hepatic, and gastrointestinal also was associated with hypolipidemic effect. Antioxidant and reactive oxygen species scavenging properties in Triphala have been observed [31],[32].

The essential oils of Rhynchosia minima, Cistanche phelypaea and Striga hermonthica exhibited antioxidant activity [9],[33],[34].

A significantly high inhibition of lipid peroxidation activity up to $89 \%$, and that depended on the amount of phenolic compounds produced by the Usnea longissima[35],[36],methanol extracts of $U$. longissima has strong antioxidative and antigenotoxic effects [37].

Curcuma longa essential oils revealed antioxidant activity and reduced the concentration of DPPH free radical [38].Natural Natural preservatives of $C$. longa as phenolic curcuminoids, essential oil, has significant antioxidant activity [39]. Curcumin improved the antioxidant status and partially protected against the adverse effects of Aflatoxin B1[40]. C. longa extract was rich in cinnamaldehyde, curcumin, and berberin, and exhibited less antioxidant activity [41]. Methanolic extracts of C. longa rhizome exhibited the highest radical scavenging activity associated with the higher concentration of phenolic content [42]. Ethanolic extracts of $C$. longa has antioxidant activities more than aqueous extract [43]. There was significant difference in total phenolic content and antioxidant activity for turmeric extract[44]. C. longa revealed reduction of oxidative stress and attenuates the development of fatty streaks in rabbits fed a high-cholesteroldiet[45]. The turmeric oil not only retained the antioxidant activity but also showed significantly higher antioxidant activity indicating that the spice constituents were resistant to thermal denaturation[46].

Oil of Nigella sativa seeds possessed reproducible antioxidant effects, particular thymoquinine [47]. Shoots extracts of $N$. sativa exhibitedhigher DPPH radical scavenging, reducing and chelating activities than roots [48]. Essential oil of black cumin provided antioxidant activity equivalent to or higher than those of synthetic antioxidants and could be a better natural antioxidant [49].N. sativa extract and Curcumin revealed reducing power and antioxidative potentials attributed to high total phenolic contents and possessed valuable as food preservative and nutritional health supplements [50] .N. sativa increased the superoxide dismutase, glutathione peroxidase activities and decreased the lipid peroxidation, myeloperoxidase activity, preserve the cell membrane integrity and prevented oxidative stress by scavenging reactive oxygen species [51-55].Black cumin seed oil, and its fractions exhibited moderate antioxidant; the phospholipid exhibited greater antioxidant followed by glycolipids and neutral lipids [56].

Extracts from young flowers and leaves of Azadirachta indica has strong antioxidant potential. An indicator of oxidative stress, prompting the recommendation to use neem as a vegetable bitter tonic to promote good health [57]. Ethanol extracts of $A$. indica revealed the highest total flavonoid content and the ethyl acetate extracts showed the highest inhibition of lipid peroxidation [58]. Neem protected against chemically induced carcinogens and liver damage by boosting antioxidant levels[59].A. indica extracts were added to the cosmetic preparations due to their antioxidant property, topical anti-inflammatory property, anti-dermatitis and antiacne [60] .

\section{Methodology}

\subsection{DPPH radical scavenging assay}

DPPH (2,2-diphenyl-1-picryl hydazyl) is usually used as a reagent to evaluate free radical screening activity of antioxidants. DPPH is stable free radical and accepts an electron or hydrogen radical to become a stable diamagnetic molecule [61]. The reduction activity of DPPH radical is determined by the decrease in absorbance at $517 \mathrm{~nm}$ induced by antioxidants. N-Propyl gallate is the reagent used as standard.The extracts are able to reduce the stable radical DPPH to the yellow colored diphenylpicrylhydrazine.

DPPH is a commercially available stable free radical, which is purple in colour. The antioxidants' molecules present in the plant extracts, when incubated, react with DPPH and converted it into diphenylhydazine, which is yellow in colour. The degree of discoloration of purple to yellow was measured at $517 \mathrm{~nm}$, which is a measure of which is scavenging potential of plant extracts [62].

The DPPH radical scavenging was determined with some modifications [63]. $5 \mathrm{mg}$ of the plant crude extracts samples were dissolved in $1 \mathrm{ml}$ of Dimethyl Sulphoxide (DMSO) while DPPH was prepared in ethanol $(300 \mu \mathrm{M}) .10 \mu 1$ of plant 
extracts was added to $90 \mu \mathrm{l}$ of DPPH solution; in 96-wells plate, the test samples were allowed to react with $2.2 \mathrm{Di}$ (4tert-octylphenyl)-1-picryl-hydrazyl stable free radical (DPPH) for half an hour at $37^{\circ} \mathrm{C}$. After incubation, decrease in absorbance was measured at $517 \mathrm{~nm}$ using multiplate reader spectrophotometer. Percentage radical scavenging activity by samples was determined in comparison with a DMSO treated control group. All tests and analysis were run in triplicate. The DPPH radical scavengingactivity of plant extract was calculated as percentage inhibition.

$\%$ Inhibition of DPPH radical $=\times 100 \frac{\text { Control-Test }}{\text { Control }}$

\section{2. Iron chelating activity assay}

The iron chelating ability was determined according to the modified method [64]. Briefly, the Fe+2 were monitored by measuring the formation of ferrous ion-ferrozine complex. The experiment was carried out in 96 microtiter plate. $50 \mu 1$ of two $\mathrm{mM} \mathrm{FeCl} 2$ was added to one $\mathrm{ml}$ of the extract $(5 \mathrm{mg} / \mathrm{ml})$. The reaction was initiated by adding $0.2 \mathrm{ml}$ of $5 \mathrm{mM}$ ferrozine. The mixture was vigorously shaken and left at room temperature for 10 minimums; the absorbance was measured at $562 \mathrm{~nm}$. EDTA was used as standard, and DMSO as control. All tests and analysis were run in triplicate. The percentage inhibition offerrozine-Fe2+complex formation was calculated as:

$\%$ Inhibition of Iron chelating $=\times 100 \frac{\text { Control-Test }}{\text { Control }}$

\section{Results and discussion}

The scavenging effect of methanol extracts with the DPPH radical is in the following order: P. granatum (71 \pm 0.03$), T$. chebula $(68 \pm 0.01), C$. phelypaea $(57 \pm 0.01), S$. argel $(48 \pm 0.01)$ and $U$. molliuscula. $(41 \pm 0.01)$. The scavenging effect of aqueous extracts with the DPPH radical is in the following order: P. granatum $(73 \pm 0.01), T$. chebula (66 \pm 0.02$), C$. phelypaea (55 \pm 0.02$), H$. abysinica $(48 \pm 0.11)$ and mixture of $C$. phelypaea and $H$. abyssinica (46 \pm 0.05$)$. Table (1).

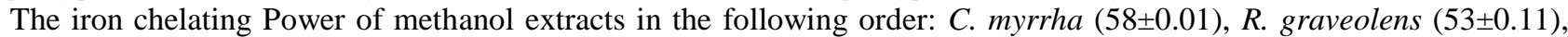
A.lebbeck (47 \pm 0.01$)$, mixture of Solenstemma argel,Trigonella foenum - graecum and Cymbopogon proximus $(46 \pm 0.02)$ and $U$. molliuscula. $(44 \pm 0.01)$. The iron chelating Power of aqueous extracts in the following order: $A$. indica

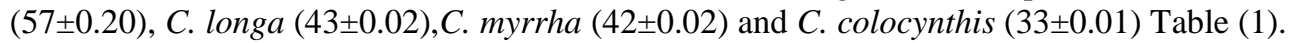

The investigation of nineteen Sudanese medicinal plants was based on their use by traditional uses for treatment of gastrointestinal tract infections. The experimental data of these species reveal that some extracts are highly having the effect of scavenging free radical and iron chelating power.

Cysteine, glutathione, ascorbic acid, tocopherol, flavonoids, tannins and aromatic amines reduced DPPH by their hydrogen donating activity [65],[66].It has been established that tannins and flavonoids have strong free radical scavenging and antiinflammatory activities [66]. Flavonoids possess antioxidative and radical scavenging properties and regulate cellular activities of the inflammation-related cells which induced mast cells, macrophages, lymphocytes and neutrophils. For instance, some flavonoids inhibit histamine release from mast cells, and others inhibit T-cell proliferation [67]. Antioxidants are also included in formulations to prevent deterioration from oxidation. In this regard, antioxidants are grouped into three categories. The first, true antioxidants for anti-oxygen probably inhibit oxidation by reacting with free radicals. The second which are reducing agents, have a lower redox potential than the drug or adjuvants which they are intended to protect and are therefore, more readily oxidized. The third are antioxidant synergist, which usually have little antioxidants effect themselves but probably enhance the action of true antioxidants by reacting with heavy ions, which catalyze oxidation [68].

The aqueous and acetone extract of $S$. hermonthica was further separated into aqueous and ethyl acetate fraction and assayed for their in vitro antioxidants properties using 2,2-diphenyl-1-picryl hydrazyl (DPPH). The crude extract exhibited a weak antioxidant activity. Luteolin is the mainDPPH radical scavenger of the ethyl acetate fraction isolate from Striga hermonthica [34].Plants Plants and their products have been used for many years for human health. There are still many plants, which have various medicinal values but still not explored and used. Plants contain many novel compounds with medicinal value, which need scientific exploration. The free radicals are produced in aerobic cells due to consumption of oxygen in cell growth [69],[70].

Free radical cause decrease in membrane fluidity, loss of oxygen receptor activity and damage to membrane protein leading to death. These free radicals are involved in different diseases like cancer, cardiovascular disease, diabetes, rheumatoid arthritis, epilepsy and degradation of essential fatty acids [69-71]. Antioxidant helps in treatment of above diseases. Phenolic compounds of $P$. granatum, A. nilotica, T. chebula, C. colocynthis, S. argel, U.molliuscula, C. longa, $N$. sativa and $A$. indica can be referred to be responsible for the antioxidants activity. 
Table 1:Antioxidant Activity of Different Medicinal Plants Using DPPH Screening and Iron Chelating Power Methods

\begin{tabular}{|c|c|c|c|c|}
\hline No & Tested material & Extract & RSA $\% \pm$ STD & Iron chelating $\% \pm \mathrm{STD}$ \\
\hline \multirow[b]{2}{*}{1} & \multirow{2}{*}{ Commiphora myrrha (resin) } & $\mathrm{Me} \mathrm{OH}$ & $31 \pm 0.04$ & $58 \pm 0.01$ \\
\hline & & $\mathrm{H} 2 \mathrm{O}$ & $42 \pm 0.02$ & $42 \pm 0.02$ \\
\hline \multirow{2}{*}{2} & \multirow{2}{*}{ Punica granatum ( Fruits peel) } & $\mathrm{Me} \mathrm{OH}$ & $71 \pm 0.03$ & $35 \pm 0.03$ \\
\hline & & $\mathrm{H} 2 \mathrm{O}$ & $73 \pm 0.01$ & $18 \pm 0.03$ \\
\hline \multirow{2}{*}{3} & \multirow{2}{*}{ Acacia nilotica (Gum) } & $\mathrm{MeOH}$ & $10 \pm 0.08$ & $38 \pm 0.03$ \\
\hline & & $\mathrm{H} 2 \mathrm{O}$ & $24 \pm 0.08$ & $30 \pm 0.01$ \\
\hline \multirow{2}{*}{4} & \multirow{2}{*}{ Ruta graveolens (Aerial parts) } & $\mathrm{MeOH}$ & $29 \pm 0.03$ & $(53 \pm 0.11)$ \\
\hline & & $\mathrm{H} 2 \mathrm{O}$ & $33 \pm 0.01$ & $04 \pm 0.01$ \\
\hline \multirow{2}{*}{5} & \multirow{2}{*}{ Rhynchosia minima (Roots) } & $\mathrm{MeOH}$ & $19 \pm 0.04$ & $03 \pm 0.02$ \\
\hline & & $\mathrm{H} 2 \mathrm{O}$ & $27 \pm 0.07$ & $11 \pm 0.02$ \\
\hline \multirow{2}{*}{6} & \multirow{2}{*}{ Hydnora abyssinica (Fruits ) } & $\mathrm{MeOH}$ & $(10 \pm 0.05)$ & $04 \pm 0.01$ \\
\hline & & $\mathrm{H} 2 \mathrm{O}$ & $48 \pm 0.11$ & $(03 \pm 0.1)$ \\
\hline \multirow{2}{*}{7} & \multirow{2}{*}{ Haplophylum tuberculatum (Aerial parts) } & $\mathrm{MeOH}$ & $35 \pm 0.04$ & $34 \pm 0.03$ \\
\hline & & $\mathrm{H} 2 \mathrm{O}$ & $29 \pm 0.04$ & $09 \pm 0.03$ \\
\hline \multirow{2}{*}{8} & \multirow{2}{*}{ Terminalia chebula (Fruits) } & $\mathrm{MeOH}$ & $68 \pm 0.01$ & $26 \pm 0.02$ \\
\hline & & $\mathrm{H} 2 \mathrm{O}$ & $66 \pm 0.02$ & $13 \pm 0.01$ \\
\hline \multirow{2}{*}{9} & \multirow{2}{*}{ Cistanche phelypaea (Aerial parts) } & $\mathrm{MeOH}$ & $57 \pm 0.01$ & $07 \pm 0.03$ \\
\hline & & $\mathrm{H} 2 \mathrm{O}$ & $55 \pm 0.02$ & $09 \pm 0.03$ \\
\hline \multirow{2}{*}{10} & \multirow[b]{2}{*}{ Striga hermonthica (Stem) } & $\mathrm{MeOH}$ & $33 \pm 0.01$ & $38 \pm 0.02$ \\
\hline & & $\mathrm{H} 2 \mathrm{O}$ & $32 \pm 0.01$ & $07 \pm 0.04$ \\
\hline \multirow{2}{*}{11} & \multirow{2}{*}{ Usnea (Aerial parts) } & $\mathrm{MeOH}$ & $41 \pm 0.01$ & $44 \pm 0.01$ \\
\hline & & $\mathrm{H} 2 \mathrm{O}$ & $16 \pm 0.03$ & $22 \pm 0.03$ \\
\hline \multirow{2}{*}{12} & \multirow{2}{*}{ Solenostemma argel (Leaves) } & $\mathrm{MeOH}$ & $48 \pm 0.01$ & $17 \pm 0.01$ \\
\hline & & $\mathrm{H} 2 \mathrm{O}$ & $35 \pm 0.01$ & $14 \pm 0.03$ \\
\hline \multirow{2}{*}{13} & \multirow{2}{*}{ Citrullus colocynthis (Fruits) } & $\mathrm{MeOH}$ & $29 \pm 0.01$ & $18 \pm 0.02$ \\
\hline & & $\mathrm{H} 2 \mathrm{O}$ & $20 \pm 0.02$ & $33 \pm 0.01$ \\
\hline 14 & Curcuma long $a$ (Roots) & $\mathrm{MeOH}$ & $36 \pm 0.01$ & $25 \pm 0.02$ \\
\hline & Carcuma tonga (NoOts) & $\mathrm{H} 2 \mathrm{O}$ & $14 \pm 0.04$ & $43 \pm 0.02$ \\
\hline 15 & Albizia lebbeck (Leaves) & $\mathrm{MeOH}$ & $20 \pm 0.01$ & $47 \pm 0.01$ \\
\hline & & $\mathrm{H} 2 \mathrm{O}$ & $13 \pm 0.02$ & $25 \pm 0.01$ \\
\hline 16 & Nigolla sativa (seeds & $\mathrm{MeOH}$ & $06 \pm 0.01$ & $43 \pm 0.02$ \\
\hline 10 & Nigella sattva (seeds) & $\mathrm{H} 2 \mathrm{O}$ & $24 \pm 0.10$ & $45 \pm 0.7$ \\
\hline 17 & Mixture 1(Aerial parts, Leaves, seeds) & $\mathrm{MeOH}$ & $35 \pm 0.02$ & $46 \pm 0.02$ \\
\hline 17 & Mnxture I(Aerral parts, Leaves, seeds) & $\mathrm{H} 2 \mathrm{O}$ & $31 \pm 0.02$ & $12 \pm 0.03$ \\
\hline 18 & Mixture 2(A erial narts Fr & $\mathrm{MeOH}$ & $39 \pm 0.06$ & $10 \pm 0.01$ \\
\hline 10 & 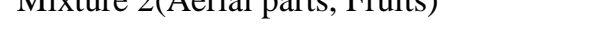 & $\mathrm{H} 2 \mathrm{O}$ & $46 \pm 0.05$ & $(30 \pm 0.2)$ \\
\hline 19 & Azadirachta indica(gum) & $\mathrm{MeOH}$ & $29 \pm 0.06$ & $34 \pm 0.02$ \\
\hline 19 & Azaatrachia inatca(gum) & $\mathrm{H} 2 \mathrm{O}$ & $08 \pm 0.03$ & $57 \pm 0.20$ \\
\hline & n-propyl gallate & & $75 \%$ & \\
\hline & EDTA & & & $95 \%$ \\
\hline
\end{tabular}

Mixture 1: Solenostemma argel,Trigonella foenum - graecum and Cymbopogon proximus

Mixture 2: Cistanche phelypaea and Hydnora abyssinica

The results of DPPH test as it can be seen in Table (1) indicate that RSA\% of aqueous extracts of $P$. granatum, $H$ .abyssinica, T. chebula, and mixture of $H$. abyssinica with $C$. phelypaea are higher than methanolic extracts, which show aqueous extracts are potent antioxidants. These results reveal an existence of phenolic compounds such as flavonoids found in aqueous extracts, which are powerful antioxidant and have good radical scavenging activities than other study plants [72].This This study suggests that compounds with antioxidants activity (phenolic compounds) are found more in aqueous extract of $P$. granatum, H. abyssinica and T. chebula than methanolic extracts.

In recent years, there has been growing interest in the role of free radical in cancer, atherosclerosis and ageing and their prevention using antioxidants [73]. Our attention has been focused particular; nineteen medicinal plants commonly used Sudanese medicinal plants. DPPH scavenging activity has been used by various researchers as a quick and reliable parameter to assess the in vitro antioxidant activity of crude plant extracts [74].With With the DPPH test the ability of a compound to act as donor for hydrogen atoms electrons is measured spectrophotometrically, and the extracts of $P$. granatum, T. chebula, C. phelypaea, S. argel and seemed to be good scavengers of reactive oxygen species.

Some variation in the extent of extract antioxidant activity was observed with each type of assay used in this study. The extracts of $P$. granatum, $T$. chebula and C. phelypaea, had good DPPH scavenging activity, but had low iron chelating power activity, while the extracts of $A$. lebbeck and A. indica had relatively high antioxidant potential, according to iron chelating test. These differences may have been due to different antioxidant mechanisms. The methanolic and aqueous 
extracts of $P$. granatum and $T$. chebula exhibited strong antioxidant activity. Previous phytochemical studies on these plants, have indicated the presence of flavonoids and phenolic compounds that are responsible for the strong antioxidant properties of these plants. In light of this evidence, these bioactive substances (antioxidants) could have extranutritional properties and a novel role in diet-disease relationships. Additional studies are necessary to show the radical scavenging activity under physiological conditions and to determine whether there is any link between their antiradical properties and their biological effects [75].Some Some of the of the experimental plants showed moderate to low antioxidant activity in methanolic and aqueous extracts. The extracts were found to have a different level of antioxidant activity. The antioxidant activity of the five plants $C$. phelpaea, S. argel, U. molliuscula, C. myrrha and mixture of $C$. phelypaea and $H$. abyssinica are moderately in both methanolic and aqueous extracts.

The iron chelating power of methanolic and aqueous extracts of C. myrrha, R. graveolens A. indica and C. longa, showed good iron chelating activity. In mammals, iron was trapped by specific proteins, when iron was mobilized; it becomes extremely dangerous for cells and tissues entering a redox cycle that generates toxic free radicals, leading to lipid peroxidation, protein oxidation and DNA damage. There was evidence of iron involvement in the pathogenesis of neoplasia, neurodegenerative diseases, rheumatoid arthritis, xenobiotic intoxication, post-ischaemic reperfusion, malaria, haemochromatosis and thalassemias [75].

\section{Conclusion}

The phenolic, flavonoid and terpenoids compounds appear to be responsible for the antioxidant activities of the extracts of all effective plants tested in the present study. From these results, it is generally clear that the methanolic and water extracts have powerful antioxidant activities against various antioxidant systems in vitro, and these plants can be used as an easily accessible source of natural antioxidants and as a possible food supplement or in pharmaceutical applications.

\section{Acknowledgement}

The authors would like to thank the Department of Biochemistry of Medicinal and Aromatic Plants Research Institute for financial support, Department of Microbiology of Medicinal and Aromatic Plants Research Institute-Street for the laboratory facilities.

\section{References}

[1] Chakraborty, P., Kumar, S., Dutta,D., Gupta,V.(2009).Role of Antioxidants in Common Health Diseases. Research J. Pharm. and Tech.2 (2):238-244.

[2] Staners, S.A., Hughes,T., Kelly,N., Buttriss, J,A.(2004).Review of the Quideriological Evidence of the Antioxidants Hypothesis. Publ. Health Nutr.7:407-422.

[3] Tiwari, P and Patel, R. K. (2011). Total Phenolics and Flavonoids and Antioxidant Potential of Draksharishta Prepared by Traditional and Modern Methods. Pharmacologyonline 3: 1072-1082.

[4] Murthy, K.N., Reddy, V.K., Veigas, J.M., Murthy, U.D. (2004). Study on Wound Healing Activity of Punica granatumPeel.J Med Food. 7 (2):256-9.http://dx.doi.org/10.1089/1096620041224111.

[5] Vijayasanthi,M., Kannan,V., Venkataswamy,R., Doss, A. (2012). Evaluation of the Antibacterial Potential of Various Solvent Extracts of Acacia niloticalinn. Leaves. Hygeia.J.D.Med. 4 (1):91-96.

[6] Rangsriwong, P., Rangkadilok, N., Satayavivad, J., Gotoc, M., Shotipruk, A.(2009). Subcritical Water Extraction of Polyphenolic Compounds from Terminalia chebulaRetz. Fruits. Separation and Purification Technology. 66:51-56.http://dx.doi.org/10.1016/j.seppur.2008.11.023.

[7] El-Ashmawy, I.M., Ashry, K.M., El-Nahas, A.F., Salama, O.M. (2006).Protection by Turmeric and Myrrh against Liver Oxidative Damage and Genotoxicity Induced by Lead Acetate in Mice. Basic Clinical and Pharmacology and Toxicology. 98 (1):327.http://dx.doi.org/10.1111/j.1742-7843.2006.pto 228.x.

[8] Auffray B. (2007).Protection against Singlet Oxygen, the Main Actor of Sebum Squalene Peroxidation during Sun Exposure, Using Commiphora myrrha EssentialOil.International Journal of Cosmetic Science. 29(1):23-9.http://dx.doi.org/10.1111/j.1467-2494.2007.00360.x.

[9] Aboul-Enein, A. M., Abu El-Ela, F., Shalaby, E.A., El-Shemy, H.A. (2012). Traditional Medicinal Plants Research in Egypt:Studies of Antioxidant and Anticancer Activities. Journal of Medicinal Plants Research.6 (5):689-703.

[10] El-Kar, C., Ferchichi, A., Attia, F., Bouajila, J. (2011). Pomegranate (Punica granatum) Juices: Chemical Composition, Micronutrient Cations, and Antioxidant Capacity. Journal of Food Science.76(6):795-800.http://dx.doi.org/10.1111/j.1750-3841.2011.02211.x.

[11] Orak, H. H., Demirci, A. Ş., Gümüş, T.(2011).Antibacterial and Antifungal Activity of Pomegranate (Punicagranatum L.cv.) Peel. EJEAFChe, 10 (3):1958-1969.

[12] Ardekania M. RS., Hajimahmoodia, M., Oveisib, M. R., Sadeghib, N., Jannatc, B., Ranjbara, A. M., Gholamb, N., Moridib, T.(2011). Comparative Antioxidant Activity and Total Flavonoid Content of Persian Pomegranate (Punica granatumL.) Cultivars. Iranian Journal of Pharma- ceutical Research.10 (3):519-524.

[13] Akbarpour, V., Hemmati, Kh,Sharifani, M.(2009).Physical and Chemical Properties of Pomegranate (Punica granatumL.) Fruit in Maturation Stage.American-Eurasian Journal of Agriculture and Environmental Sciences. 6(4): 411-416.

[14] Reddy,M. K., Gupta, S. K., Jacob, M. R., Khan, Sh. I., Ferreira, D.(2007).Antioxidant, Antimalarial and Antimicrobial Activities of TanninRich Fractions, Ellagitannins and Phenolic Acids from Punica granatum L. J Planta Med. 73(5):461-467.http://dx.doi.org/10.1055/s-2007$\underline{967167 .}$.

[15] Ajaikumar, K.B., Asheef, M., Babu, B.H., Padikkala, J.(2004).The Inhibition of Gastric Mucosal Injury by Punica granatum L. (pomegranate) Methanolic Extract. Journal of Ethnopharmacology. 96(1):171-176.

[16] Koko, W. S., Osman, E. E., Galal, M. (2009). Antioxidant and Antiglycation Potential of Some Sudanese Medicinal Plants. BoletínLatinoamericano y del Caribe de Plant as Medicinales y Aromáticas. 8(5):402 - 411. 
[17] Vadivel, V. and Biesalski, H.K.(2012).Total Phenolic Content, In vitro Antioxidant Activity and type II Diabetes Relevant Enzyme Inhibition Properties of Methanolic Extract of Iraditionally Processed Underutilized Food Legume, Acacia nilotica(L.) Willd ex. Delile. Food Research Journal 19.(2): 593-601.

[18] Ali, A., Akhtar, N., Khan, B. A., Khan, M. S., Rasul, A., UZ-Zaman, Sh., Khalid, N., Waseem, Kh., Mahmood, T., Ali, L. (2012). Acacia nilotica: A Plant of Multipurpose Medicinal uses .Journal of Medicinal Plants Research. 6 (9):1492-1496.

[19] Diwan, R., Shinde, A., Malpathak, N. (2012).Phytochemical Composition and Antioxidant Potential of Rutagraveolens L. In Vitro Culture Lines. Journal of Botany. 2012:1-6.http://dx.doi.org/10.1155/2012/685427.

[20] Ratheesh, M., Shyni, G.L., Helen, A. (2009). Methanolic Extract of Ruta graveolens L. Inhibits Inflammation and Oxidative Stress in Adjuvant Induced Model of Arthritis in Rats. Inflammopharmacology. 17(2):100-105.http://dx.doi.org/10.1007/s10787-009-8044-0.

[21] Chang ,C. L. and Lin, C. S.(2011).Phytochemical Composition, Antioxidant Activity, and Neuroprotective Effect of Terminalia chebulaRetzius Extracts. Evidence-Based Complementary and Alternative Medicine .2012:1-7.

[22] Hazra, B., Sakar, R., Biswas, S., Mandal, N.(2010).Comparative Study of the Antioxidant and Reactive Oxygen Species Scavenging Properties in the Extracts of the Fruits of Terminalia chebula, Terminalia belerica, and Emblica officinalis.BMC Complementary and Alternative Medicine.10-20 http://www.biomedcentral.com/1472-6882/10/20.http://dx.doi.org/10.1186/1472-6882-10-20.

[23] Mahesh,R., Bhuvana,Sh., Begum,V. M.( 2009). Effect of Terminalia chebula Aqueous Extract on Oxidative Stress and Antioxidant Status in the Liver and Kidney of Young and Aged Rats. Cell Biochem Funct.27:358-363.http://dx.doi.org/10.1002/cbf.1581.

[24] Krishnamoorthy, P.1., Vaithinathan, S., Vimal Rani, A. Bhuvaneswari, A.(2007).Effect of Terminalia chebulaFruit Extract on Lipid Peroxidation and Antioxidative System of Testis of Albino Rats. African Journal of Biotechnology. 6 (16):1888-1891.

[25] Bhattacharya, S., Chaudhuri, S.R., Chattopadhyay S., Bandyopadhyay, S. K.(2007).Healing Properties of Some Indian Medicinal Plants against Indomethacin-Induced Gastric Ulceration of Rats. Journal of Clinical Biochemistry and Nutrition. 41:106114.http://dx.doi.org/10.3164/jcbn.2007015.

[26] Suchalatha,S and Devi, C.S. (2007).Antioxidants Activity of Ethanolic Extract of Terminalia chebula Fruit against Isoproterenol - Induced Oxidative Stress in Rats. Indian Journal of Biochemistry and Biophysics. 42:246-249.

[27] Cheng, H. Y., Lin, T.C., Yu, K.H., Yang, C.M., Lin, C.C. (2003). Antioxidant and Free Radical Scavenging Activities of Terminalia chebula. Journal of Biology and Pharmacy. Bull. $26(9): 1331-1335$.

[28] Lee, H.S., Won,N. H., Kim,K. H., Lee,H., Jun, W., Lee, K.W. (2005).Antioxidant Effects of Aqueous Extract of Terminalia chebulaInVivoandIn Vitro. Biol. Pharm. Bull. 28(9):1639-1644.http://dx.doi.org/10.1248/bpb.28.1639.

[29] Dhanalakshmi,S., Devi,R.S.,Srikumar, R.,Manikandan, S., Thangaraj. R. (2007). Protective Effect of Triphala on Cold Stress- Induced Behavioral and Biochemical Abnormalities in Rats. Pharmaceutical Society of Japan.127 (11): 1863-1867.

[30] Rahman, M. S., Begum, B., Chowdhury, R., Rahman, K. M., Rashid, M. A.(2008).Preliminary Cytotoxicity Screening of Some Medicinal Plants of Bangladesh. Journal of. Pharmacy. Sci.7 (1):47-52.

[31] Rahmatullah,M., Islam,T., Hasan, E., Ahmed,R., Jamal, F., Jahan, R., Khatun, A., Nahar, N., Ahsan, S., Nahar,A., Ahmad, I. (2010).A survey of Medicinal Plants used by the Folk Medicinal Practitioners of Shetabganjvillage in Dinajpur District, Bangladesh. American-Eurasian Journal of Sustainable Agriculture.4 (2):196-203.

[32] Saravanan,S., Srikumar,R., Manikandan, S., Parthasarathy, N.J., Devi, R.(2007).Hypolipidemic Effect of Triphala in Expermentally Induced Hypercholeseremic Rats. Pharmaceutical Society of Japan.127 (2):385-388.

[33] Gundidza ,M., Gweru,N., Magwa,M. L., Ramalivhana, N. J., Humphrey, G., Samie, A., Mmbengwa, V. (2009).Phytochemical Composition and Bio- logical Activities of Essential Oil of Rhynchosia minima (L) (DC) (Fabaceae). African Journal of Biotechnology. 8 (5):721-724.

[34] Kiendrebeogo, M., Dijoux-Franca, M.G., Lamien,C. E. Meda,A., Wouessidjewe, D., Nacoulma, O.G. (2005) .Acute Toxicity and Antioxidant Property of Striga hermonthica(Del.) Benth (Scrophulariaceae). African Journal of Biotechnology. 4 (9):919-922.

[35] Behera,B. C., Verma, N., Sonone, A., Makhija,U. (2009). Optimization of Culture Conditions for Lichen Usnea ghattensis G. Awasthi to Increase Biomass and Antioxidant Metabolite Production.Food Technology and Biotechnology.47(1):7-12.

[36] Heng, L., Yamamoto, Y., Liu, Y., Jung, J. S., Kahng, H. Y., Koh, Y. J., Hur, J.S.(2010).The In Vitro Antioxidant Properties of Chinese Highland Lichens. Journal of Microbiology and Biotechnology.20 (11):1524-1528.http://dx.doi.org/10.4014/jmb.1003.03029.

[37] Agar, G., Aslan, A., Sarioglu, E. K., Alpsoy, L., Ceker, S. (2011).Protective Activity of the Methanol Extract of Usnea longissimaagainst

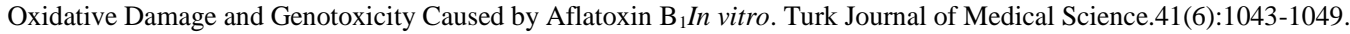

[38] Sacchetti ,G., Maietti,S., Muzzoli,M., Scaglianti,M., Manfredini, S., Radice, M., Bruni, R.(2005) .Comparative Evaluation of 11 Essential Oils of Different Origin as Functional Antioxidants, Antiradicals and Antimicrobials in Foods. Food Chemistry .91:621632.http://dx.doi.org/10.1016/j.foodchem.2004.06.031.

[39] Singh,A., Sharma,P.K., Garg,G. (2010).Natural Products as Preservatives. International Journal of Pharma and Bio Sciences. 1(4):601-612.

[40] Gowda, N. K., Ledoux, D. R., Rottinghaus,G. E., Bermudez, A. J., Chen, Y. C.(2008). Efficacy of Turmeric (Curcuma longa), Containing a known Level of Curcumin, and a Hydrated Sodium Calcium aluminosilicate to Ameliorate the Adverse Effects of Aflatoxin in Broiler Chicks. Poult Science. 87(6):1125-1130.http://dx.doi.org/10.3382/ps.2007-00313.

[41] Jang, H-D., Chang,K-Sh., Huang, Y-Sh., Hsu,Ch-L., Lee,Sh-H ., Su,M-Sh.(2007).Principal Phenolic Phytochemicals and Antioxidant Activities of Three Chinese Medicinal Plants. Food Chemistry.103: 749-756.http://dx.doi.org/10.1016/j.foodchem.2006.09.026.

[42] Mongkolsilp, S., Pongbupakit,I., Sae-Lee N ., Sitthithaworn ,W. (2004).Radical Scavenging Activity and Total Phenolic Content of Medicinal Plants used in Primary Health Care.SWU J Pharm Sci.9 (1):32-35.

[43] Maizura, M., Aminah, A., Wan Aida, W. M. (2011).Total Phenolic Content and Antioxidant Activity of Kesum (Polygonum minus), Ginger (Zingiberofficinale) and Turmeric (Curcuma longa) Extract. International Food Research Journal. 18: 529-534.

[44] Quiles, J. L., Mesa, M. D., Ramírez-Tortosa, C. L., Aguilera,C. M., Battino,M. Gil, Á., Ramírez-Tortosa, M. C.(2002).Curcuma longa Extract Supplementation Reduces Oxidative Stress and Attenuates Aortic Fatty Streak Development in Rabbits.ArteriosclerThrombVasc Biol.22:1225-1231.http://dx.doi.org/10.1161/01.ATV.0000020676.11586.F2.

[45] Tiwari, V., Shanker, R., Srivastava, J., Vankar, P. S.( 2006).Change in Antioxidant Activity of Spices-Turmeric and Ginger on Heat Treatment. Electron. J. Environ. Agric. Food Chem. 5 (2):1313-1317.

[46] Salem, M. L. (2005). Review:Immunomodulatory and Therapeutic Properties of the Nigella sativa L. Seed. International Immunopharmacology 5:1749-1770.http://dx.doi.org/10.1016/j.intimp.2005.06.008.

[47] Bourgou, S., Ksouri ,R., Bellila ,A., Skandrani,I., Falleh,H., Marzouk, B.(2008).Phenolic Composition and Biological Activities of TunisianNigella sativaL. Shoots and Roots.Biologies.7:331-335.http://dx.doi.org/10.1016/j.crvi.2007.11.001.

[48] Singh,G., Marimuthu, P., De heluani, C. S., Catalan, C. (2005). Chemical Constituents and Antimicrobial and Antioxidant Potentials of Essential Oil and Acetone Extract of Nigella sativa Seeds.Journal of the Science of Food and Agriculture. 85:2297-2306. http://dx.doi.org/10.1002/jsfa.2255.

[49] El-Beshbishy, H. A., Mohamadin, A. M., Abdel-Naim, A. B. (2009) .In Vitro Evaluation of the Antioxidant Activities of Grape Seed (Vitisvinifera) Extract, Blackseed (Nigella sativa) Extract and Curcumin. Journal of Taibah University Medical Sciences.4(1):2335.http://dx.doi.org/10.1016/S1658-3612(09)70078-2. 
[50] Yoruk, O., Gur, F. O., Uyanik, H., Yasar,M., Mutlu,V., Altas,E., Baysal, E., Taysi,S.(2010).Antioxidant Effects of Nigella Sativa in the Treatment of Experimentally Induced Rhinosinusitis. Macedonian Journal of Medical Sciences. 3(2):132137.http://dx.doi.org/10.3889/MJMS.1857-5773.2010.0101.

[51] Tülüce, Y., Özko,H., Sögüt, B., Çelik, İ.( 2009) .Effects of Nigella sativa L. on Lipid Peroxidation and Reduced Glutathione Levels in Erythrocytes of Broiler Chickens. Cell Membranes and Free Radical Research. 1(1):95-99.

[52] Musa, D., Dilsiz, N., Gumushan, H., Ulakoglu, G., Bitlren, M.(2004). Antitumor Activity of an Ethanol Extract of Nigella sativa Seeds. Biologia, Bratislava.59:735-740, 2004.

[53] Kanter, M., Demir, H., Karakaya, C., Ozbek, H. (2005). Gastroprotective Activity of Nigella sativa L Oil and its Constituent, Thymoquinone against Acute Alcohol-Induced Gastric Mucosal Injury in Rats. World Journal of Gastroenterology .11(42):6662-6666.

[54] Ramadan, M.F and Mörsel, J.T. (2003). Analysis of glycolipids from black cumin (Nigella sativa L.), coriander (Coriandrum sativumL.) and Niger (Guizotia abyssincaCass.) oilseeds. Journal of Food Chemistry. 80:197-204.http://dx.doi.org/10.1016/S0308-8146(02)00254-6.

[55] Paterson, P.(2009). Neem the Wonder Tree: Its Pesticide and Medicinal Applications.M.Sc Thesis. Maryland University. Washington.USA.

[56] Anokwuru, C.P., Anyasor, G.N., Ajibaye O., Fakoya O., Okebugwu P. (2011).Effect of Extraction Solvents on Phenolic, Flavonoid and Antioxidant Activities of Three Nigerian Medicinal Plants. Nature and Science.9(7):53-61.

[57] Bhowmik, D., Yadav, C. J., Tripathi,K. K., Kumar, K. P. (2010).Herbal Remedies of Azadirachta indicaand its Medicinal Application. Journal of Chemistry and Pharmacy Research. 2(1):62-72.

[58] Reddy, P.M., Gobinath,M., Rao, K.M., Venugopalaiah, P., Reena,N. (2011).A review on Importance of Herbal Drugs in Cosmetics. International Journal of Advances in Pharmacy and Nanotechnology.1 (3):121 -139.

[59] Adu, F., Gbedema, S. Y., Brown, P., Annan, K., Boamah, V. E. (2011). Antibacterial and Free Radical Scavenging Activity of Durantaplumieri, Linn. International Journal of Pharmaceutical Sciences and Research (JPSR).2 (2):282-287.

[60] Narayanaswamy,N and Balakishnan,K.P.(2011).Evaluation of Some Medicinal Plants for their Antioxidants Properties. International Journal of Pharm Tech Research.3(1):381-385.

[61] Shaheen, F., ahmad, M., khan, M. T., jalil, S., Ejaz, A., Sultankhodjaev M. N., Arfan, M., Choudhary, M. I., Rahman, A.U. (2005). Alkaloids of Aconitum Leave and their Anti-inflammatory, Antioxidant and Tyrosinase Inhibition Activities. Phytochemistry. 66: 935940.http://dx.doi.org/10.1016/j.phytochem.2005.02.010.

[62] Zhu, K., Zhou, H., Qian, H. (2006): Antioxidant and Free Radical-Scavenging Activities of Wheat Germ Protein Hydrolysates (WGPH) Prepared with Alcalase. Process Biochemistry. 41:1296-1302.http://dx.doi.org/10.1016/j.procbio.2005.12.029.

[63] Balois, M.S.(1958).Antioxidants Determination by the use of Stable Free Radical.Nature.4617:11991200.http://dx.doi.org/10.1038/1811199a0.

[64] Yokozawa,T.,Chen,C.P.,Dong,E.,Tanka,T.,Nonaka,G.I.,Nishioka,I.(1998).Study on the Inhibitory Effect Tannins and Flavonoids against the 1,1-Diphenyl-2-Picryl Hydazyl Radical.Biochem.Pharmacol.56:213-222.http://dx.doi.org/10.1016/S0006-2952(98)00128-2.

[65] Kim, H. P.,S on, K. H., Chang, H. W., Kang, S. S. (2004). Antiinflammatory Plant Flavonoids and Cellular Action Mechanisms. Journal of pharmacology .96:229-245.

[66] Parfitt, K. (1999). "Martindale ", Disinfectant and Preservatives. The Pharmaceutical Press,32 ed.1097.

[67] Barros, L., Ferreira, M.J., Guciros, B., Ferreira, I.C., Baptista, P. (2007).Total Phenols, Ascorbic Acid, $\beta$-carotene and Lycopene in Portuguese Wild Edible Mushroom and their Antioxidant Activities. Food Chemistry.103:413-420. http://dx.doi.org/10.1016/j.foodchem.2006.07.038.

[68] Singh, R., Singh, H.,Kumar, S., Arorra, S. (2007). Studies on Antioxidant Potentials of Methanol Extract/ Fraction of Acacia auriculi.ACunn.Food Chemistry.103:505. http://dx.doi.org/10.1016/j.foodchem.2006.08.019.

[69] Bondet, V.,Brand,-Williams, W., Berset,C.(1997).Kinetics and Mechanisms of Antioxidant activity Using the DPPH Free Radical Method. Lebenon-Wiss U-Technol.30:609-615.http://dx.doi.org/10.1006/fstl.1997.0240.

[70] Ona, M., Oda, E., Tanka, T., Idia, Y., Yamasakki, T., Masuoka, C.(2008). DPPH Radical ScavengingEffect on Some Constituents from the Arial Part of Lippin triphya. J. Nat Med.62 (1):101-106.http://dx.doi.org/10.1007/s11418-007-0197-9.

[71] Finkel, T and Holbrook, N.T. (2001).Oxidants, Oxidative Stress Biology of Ageing[77] Ferrali, M., Donati, D., Bambagioni, S., Fontani, M.,Giorgic, G., Pietrangelod, A.(2001).3-Hydroxy-(4H)-benzopyran-4-ones as Potential Iron Chelating Agents In Vivo. Bioorganic and Medicinal Chemistry. 9:3041-3047. http://dx.doi.org/10.1016/S0968-0896(01)00207-3.

[72] Navana, M.C., Mantilla, M.P., Martin, A. (1992). Free Radical and Antihepatotoxic Activity of Rosmarius tomentosus.Planta Med.59:312-14.

[73] Vijayanand, S., and Hemapriya, J.(2011).In vitro Antibacterial Efficacy of Peel and Seed Extracts of Punica granatumL.against Selected Bacterial Strains. International Journal of Medicobiological Research. 1(4):231-234.

[74] Ramadan, M.F., Kroh,L. W., Mörsel, J.T. ( 2003). Radical Scavenging Activity of Black Cumin (Nigella sativa L.), Coriander (Coriandrum sativumL.), and Niger (Guizotia abyssinicaCass.) Crude Seed Oils and Oil Fractions. Journal of Food Chemistry.1-9. 